Article

\title{
Wild Carpathia Future Development: From Illegal Deforestation to ORV Sustainable Recreation
}

\author{
Mihai Voda ${ }^{1, *}$, Adrian Torpan ${ }^{2}$ and Lucian Moldovan ${ }^{2}$ \\ 1 Faculty of Geography, Dimitrie Cantemir University, 3-5 Bodoni Sandor, 540545 Targu Mures, Romania \\ 2 Faculty of Geography, Babes-Bolyai University, 5-7 Clinicilor, 400006 Cluj Napoca, Romania; \\ atorpan@yahoo.com (A.T.); moldovandlucian@yahoo.com (L.M.) \\ * Correspondence: mmvoda@yahoo.com or mihaivoda@cantemir.ro; Tel.: +40-077-161-2473
}

Received: 3 November 2017; Accepted: 3 December 2017; Published: 6 December 2017

\begin{abstract}
Romanian Wild Carpathia constitutes the ultimate pristine wilderness of the old European continent. Carpathian Mountains landscape experiences and outdoor recreation represents quite unique cultural ecosystem services. The new annotations to the Forest Law are restricting any public access in the woods without authorities' pre-approval for organised sport, leisure and tourism activities. However, off road vehicle (ORV) recreation is a popular activity and a growing transparency concern of National Forest Administration Authorities that is not managed accordingly. Here we show that our ORV recreation frame model can securely allow public access and protect all Romanian mountains. Our results demonstrate how growing ORV recreation popularity can be used in an honest and open way if it is well organized and controlled. We anticipate our assay to be a starting point for a regional and national forest administration sustainable development plan. Furthermore, stopping illegal forest activities is a major target of the anti-logging movement. A well-defined assay for the ORV recreation frame model will be relevant for such developments.
\end{abstract}

Keywords: Wild Carpathia; off road vehicle (ORV); recreation frame model; ecosystem services; illegal deforestation

\section{Introduction}

Wild Carpathia beautifully quantifies the Romanian Carpathians untouched nature, first presented in the homonymous documentary film by Charlie Ottley [1], who visited the area in 2011 and decided to show it to the world in the attempt to save it through tourism development, as an alternative to extensive destruction from illegal deforestation. The huge success of the first Wild Carpathia film convinced the Romanian Government to sponsor the next two documentaries and determined us to choose the term to cover our research area for a wider international impact.

In our opinion, the Carpathian Mountains and most deforestation areas may be accessible for off-road vehicle (ORV) leisure activities through the gravel roads network administrated by the Romanian National Forest Administration Authorities (NFAA). We propose the network to be used by the public in a sustainable way as eco-recreational routes in order to raise societal environmental awareness and to contribute to the woods salvation.

According to the Romanian Forest Law 133 [2], public access into the forest through the NFAA's gravel roads network is forbidden. Owing to the cuttings, mountain routes are closed. In many cases, illegal logging activities are taking place undisturbed, nearby human living environments [3]. We consider that ecosystem services development will open deforestation routes to off-road vehicles (ORV) recreation activities, increasing transparency and timber security.

As providing ecosystem services is increasingly seen as a solution for mountain ranges disequilibrium problems in many other countries, it is worth examining its impact in Romania, which is a well known illegal deforestation champion. 
A number of researchers have examined this issue, especially Sil et al. [4], who stated that mountain ranges have to be major ecosystem service providers all over the world. Ecosystem services include cultural heritage contributions, tourism and outdoor recreation support utilities in many other countries but not in Romania.

As compared to other European Union states, where the remaining surfaces are much smaller, Romania still has hundreds of thousands of hectares of virgin forests. The professional evaluation of the old grown woods that was coordinated by Veen during the 2001-2004 interval, identified 210,000 ha of virgin forests [5]. The results show that in Romania, the total surface of these woods remarkably decreased from two million ha to 400,000 ha in less than 100 years [5]. Actually, after the fall of the communist regime in 1989, more forest disappeared than between 1945 and 1989, when every deforested area was carefully replanted.

Increasing deforestation rates in the Carpathian Mountains were constantly reported as a lack of forest management capacity [6,7] but according to Vanonckelen and Van Rompaey [8], Carpathian Mountains are gradually greening. Deforestation activities are taking place only in local hot spots, accessible areas, close to villages and secondary roads. In our opinion, there are strong connections between NFAA employees, private land owners and NGOs. Deforested areas are intentionally abandoned so the bushes can grow fast and cover the land surfaces. In this way, the satellite images will identify transitional woodland and gradually greening areas, not illegal cuttings.

Despite all of the cuttings in the mountain woods, spruce is slowly replaced by beech in a natural recovery process along the valley access roads and ridge paths. The variations of forest values typology were proved by Brown and Reed [9] and used regularly in different mapping research of the so-called social values. However, in their study upon forest cover changes in the Iezer Mountains, Mihai et al. [10], proved that forest evidence showed important human influences in areas with already reduced natural forest surfaces. The physical capacity is overpassed and the environmental balance destroyed. No ecosystem services were provided by Wild Carpathia deciduous, coniferous or mixed forest with ecosystem values [11,12], wilderness values, environmental values and landscape values.

ORV activity amateurs have a special relationship with nature from which the importance of the mental notion of wellbeing derives. This value is neglected by the standard functional valuation when analysing what ecosystem stakeholders normally perceive. Hence, the cultural concept is linked to peoples' understanding and perception [13]. The social merit category can be described as someone appreciating the woodland for its traditional meaning, as being a location where his forefathers felt free riding horses. Nowadays, their nephews ride enduro motorbikes. In the description of recreation as a social value type, one can say that he appreciates the woodland because there he can do his personal recreational activities [14]. However, any ORV recreational model must reflect a structure where the ecosystem services are quantifiable in terms of benefits for peoples' wellbeing [15].

According to the Millennium Ecosystem Assessment (MEA) that was founded through a collaborative work between different organizations and academics around the world, it is very important to understand the inter-relations between ecosystem services and peoples' well-being. MEA is distinguishing four types of ecosystem services: provisioning, cultural, regulating and support services. Hence, ecosystem services represent all the conveniences that wild animals and the natural environment provide to people, including the supply of such entity as natural or cultural resources [16].

In order to more efficiently include the perceived values of the service beneficiaries, we have to admit that, from an international perspective, there is a need for ecosystem services valuation. All over the world, decision makers have to assess the complexity of socio-cultural and ecological values, in the insertion process to the functional values [16].

Connecting the observed patterns of ORV users to the geographical location environmental variables, the empirical modelling of recreational services is possible. An assessment was first made of the NFAA's gravel roads network, on a selective basis, and then the environmental impact of the ORV users was examined. With our proposed recreation frame model virtual platform, the online monitoring process of Wild Carpathia routes will be possible. 
Participatory mapping [17], surveys and proofs of free-ranging ORV recreation routes [18] were used to determine tracks, trails or paths connections to the gravel roads.

Wescott and Andrew [19] showed that empirical recreation indicators are avoiding any doubts in how to represent user options with available geographical data layers. Their study clearly expresses the tested interconnections between recreational manifestations and environmental variables.

Sherrouse et al. [17], developed a GIS app named SolVES that is unifying methods and concepts like eco-system services valuation and social merits reflection on maps. SolVES is important because it can be used to illustrate the interrelations between social values and the environmental features of a geographical location. It is a tool not for academics only, but also for stakeholders and decision makers. They must quantify the attitudes and preferences manifested by the social values, in connection with environmental characteristics and related ecosystem services [17].

\section{Materials and Methods}

We present an approach to develop spatial indicators of recreation patterns based on field work collected evidence of random track use across Carpathian Mountains landscape combined with high-resolution satellite images, web databases and social networks. This modelling method is very effective, requiring ORV experience and accessible spatial data layers.

Several stages have been taken in order to develop the graphic material. The first stage consisted in choosing the mountain routes and vectorizing them. Secondly, for the tracks typology elaboration, the identification of every track morphological characteristics was made on field. The trails have been chosen according to two criteria: atractivity and logging proximity. The track representativeness for the analysed mountainous massif was analysed, thus being one of the most visited mountain trails. Then the locations and density of the deforested areas were determined, especially in the proximity of the mountain trails (Figure 1).

In order to vectorize the mountain trails we have used tourist maps, topographic maps 1:25,000 and high-resolution satellite images $(30 \mathrm{~cm})$ offered by Esri, DigitalGlobe, GeoEye, Earthstar Geographics, CNES/Airbus DS, USDA, USGS, AeroGRID, IGN, GoogleEarth and the GIS User Community, whereas for the actual vectorization the ArcGis programme has been used.

Similarly, we have revealed and highlighted the deforested areas. However, in this case a comparative study was made on the orthophotomaps of the years: 2005, 2008, 2009, 2010, 2012, and 2016 accessible on the ANCPI geo-portal. Finally, in order to prove the existence and the magnitude of the deforested areas, the Corine Land Cover (CLC) database on the use of land was also employed (Figure 2).

Numerous field trips and off-road motorbike skills allowed complementary social data on track use interpretation and desired recreation features identification. Our results demonstrate that we can definitively link the observed patterns of random tracks to forest exploitation routes as better recreation experiences.

The ORV recreation frame model is developed based on remote sensing information for tracks features visualisation. All routes collected data was modelled on the regional topographic characteristics [20]. We used drones to film and take aerial pictures for 3D views and short virtual flights developed on digital elevation models correlated with satellite images.

Adding ORV routes specific description, geo-tagged photos and videos we finally obtained a comprehensive information system that generated an ORV recreational frame database using the Geomedia concept.

According to our approach, Geomedia represents the combination between MySQL web databases, maps and social networks [21]. Low value investments are needed to build a virtual platform, identify and manage the ORV recreation frame model in a cost-effective approach for natural woods future protection. 


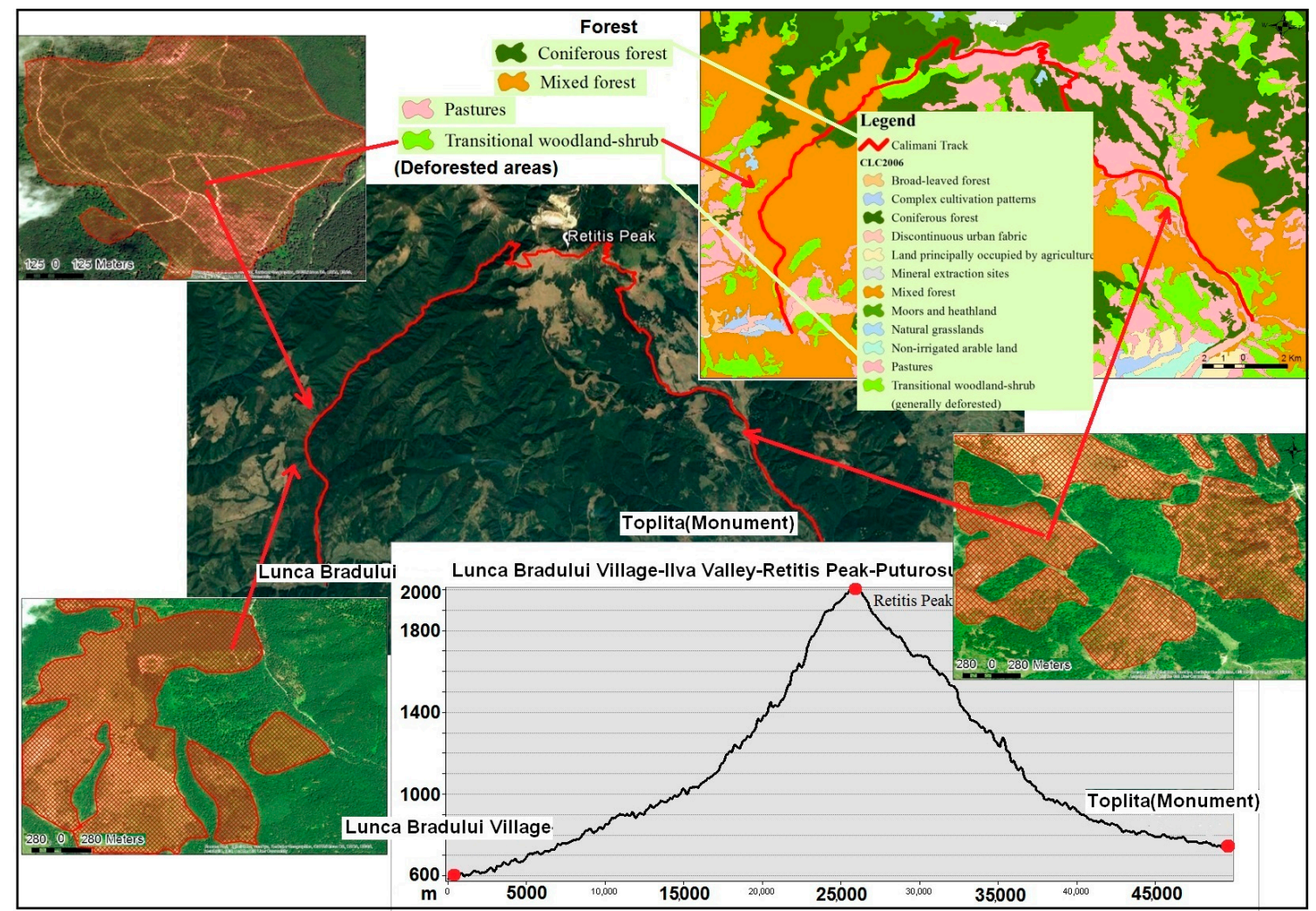

Figure 1. Lunca Bradului-Retitis Peak-Toplita ORV recreational route.

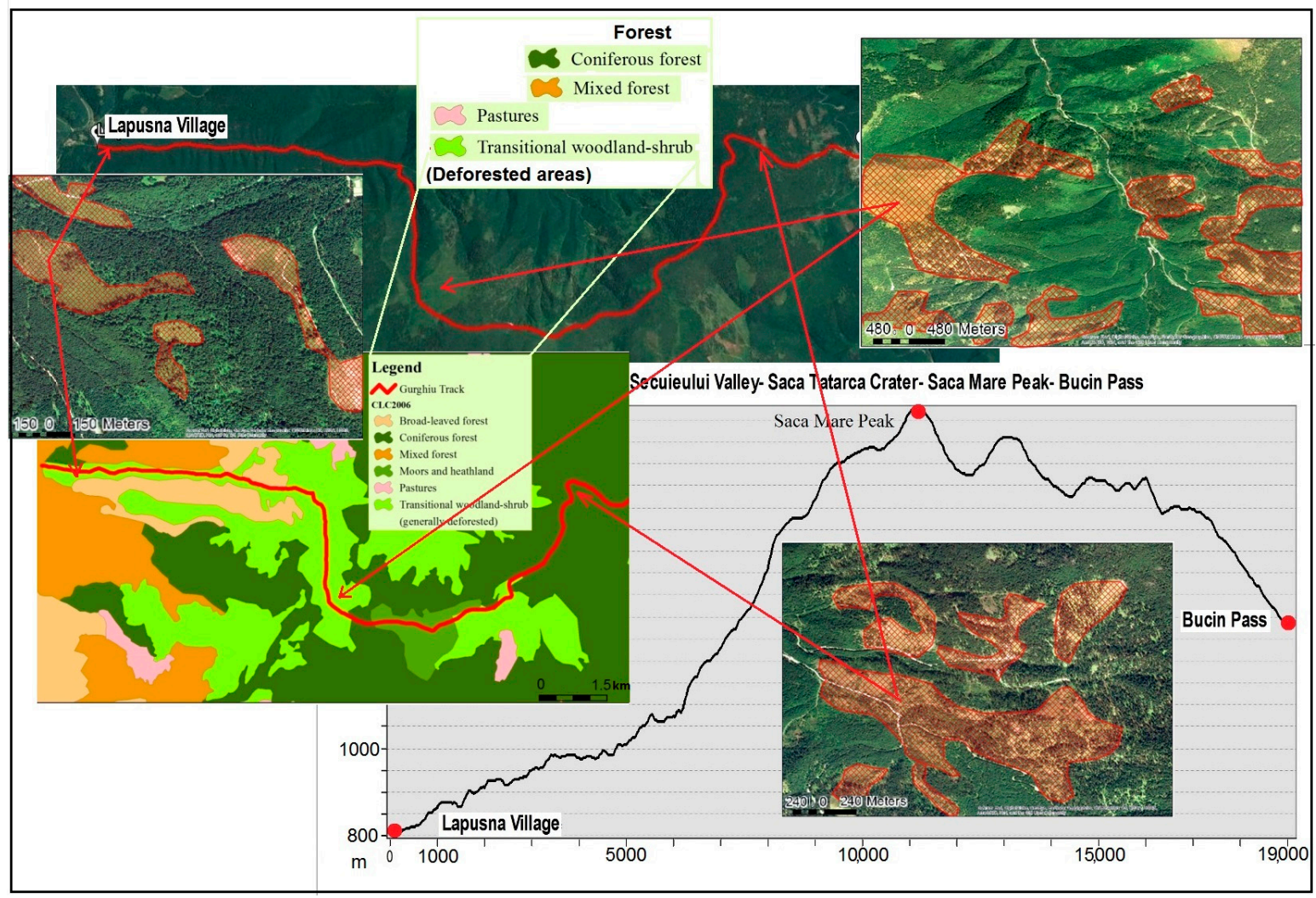

Figure 2. CLC database correlation on Lapusna-Bucin Pass ORV route deforested areas. 


\section{Results}

Although part of the adventure tourism niche, off road vehicle (ORV) recreational activities have had an important development in recent years due to the relatively free access into the Transylvanian woods and more affordable technical equipment on the market. Many ORV are kept in households of remote villages without any legal matriculation number, being used occasionally on the week-ends for recreational activities. Almost every hunter or fisherman has an old Suzuki Vitara or other 4WD vehicle for leisure purposes. Adventurers are riding Soft Enduro motorcycles like BMW 650 GS, Yamaha Tenere, XT, TT, Suzuki DR, DRZ, Honda XR, when the weather conditions allow it, from March until late October on the county roads up to the mountain gravel tracks. Competitive trail riding is mostly done by younger people with Hard Enduro motorbikes like KTM EXC, Honda CRFX or Yamaha WR to explore the wilderness. This type of recreational activity started after the end of the communist regime, more than 20 years ago when many second-hand ORV's arrived on the Romanian market especially from UK, Germany and Italy.

More than that, all over the Carpathian Mountains there is a weekend liberty movement, a small-scale migration from the city to the mountain valleys in search of the trees, grass, clean spring water and fresh air. The NFAA gravel roads constitute their main access routes into the natural environment, sometimes affected by deforestation activities. However, after the Picnic Law [22], the number of ecosystem service beneficiaries decreased and illegal cuttings increased. Very few designated areas for such recreational activities, quantifiable in terms of benefits for peoples' wellbeing, were developed by local rural authorities from mountainous vicinities, more interested in covert forest operations, for their own business.

\subsection{ORV Recreation in Transylvania Context}

Carpathian Mountain experiences through off road vehicle (ORV) recreation was amplified with the Red Bull Romaniacs competition, launched in 2004. The demand for the sport of Extreme Enduro lead Red Bull Romaniacs founder Martin Freinademetz to several editions organised in the Southern Transylvanian Mountains [23]. The competitions provided diverse ORV recreation opportunities taking into account the local environmental protection of the proposed routes. National Forest Administration Authorities (NFAA) were a partner in the organised events, restricting off road vehicles access only on the specified tracks that were crossing the mountain woods, streams and meadows.

This is how off-road vehicle recreation became a popular activity all over the Carpathian Mountains. After the 14th edition last year, the Red Bull Romaniacs has become more than a legend for ORV practitioners and the international demand for Extreme Enduro racing grew accordingly, not only for competitors, but for hundreds of ORV addicts, amateurs wanting to follow the competition tracks [23].

Romanian National Forest Administration Authorities did not manage ORV recreational activities accordingly. Apart from organised competitions that take place for a few days once a year on specific routes, approved by NFAA according to the Forest Law 133/2015, there is no legal ORV recreation frame model available.

\subsection{ORV Movement Patterns}

Tracking and analyzing the movement of ORV in the Carpathian Mountains environment between 2009 and 2017, we collected data and information for improved trail options and ORV practices. Our research has shown that the behavior of hard enduro practitioners on different parts of large meadows or dense forest can be affected by various factors, such as altitude, soil and rocks typology, grassland vegetation caracteristics and weather conditions.

In particular, correlation of ORV movements with hard enduro preferences offers the prospect of trail selection with the aim of routes optimization by accessibility selection. For example, there is a 
mud-water and rocks-tree trunks alternation that can turn the gravel road bumps into deep ridges and the tree stumps and logs into a hard enduro skilled track [3].

The tracks sections with collapses, permanent moisture, torrents and logging areas were evaluated and marked on longitudinal profile graphs. Seven types of tracks were categorized with on field collected data: gravel road in good conditions, gravel road with unstable rock fragments, clay-sand mix tracks, clay-gravel mix tracks and soil-track with unstable rock fragments (Figure 3).

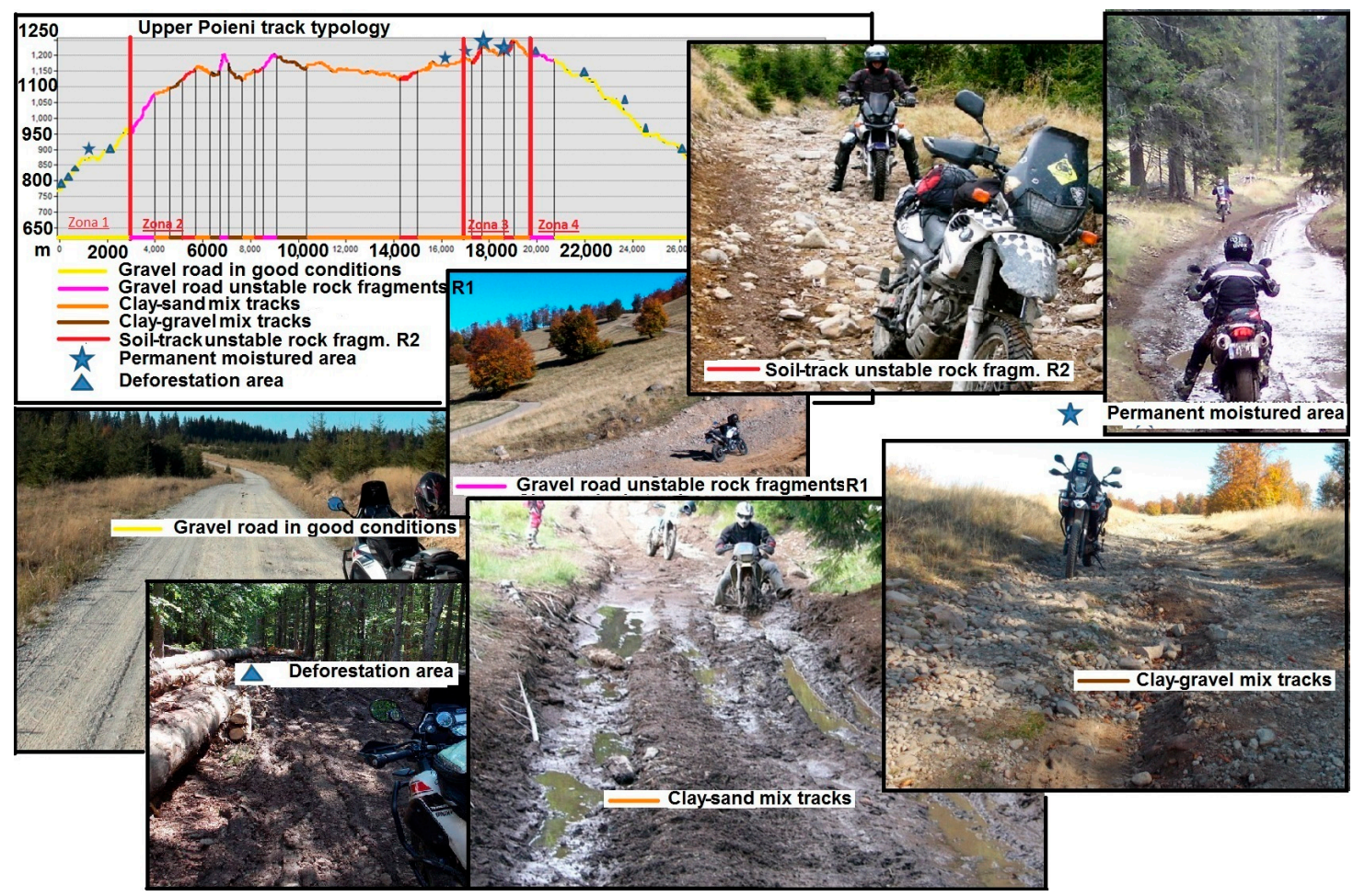

Figure 3. ORV access routes surface type distribution.

There is therefore a case for tracking and analyzing the behavior of motorbike riders and their interactions with the Carpathian Mountains environment in order to identify opportunities to improve the natural sites protection conditions through redesign of the access routes and the illegal trails (Figure 3).

Here we show the illegal random tracks that have to be closed to protect and maintain the natural areas undisturbed. Our spatial model of ORV recreation reveals that ORV tracks are often associated with natural amenities like rock outcrops and dry stream beds accessible via the existing forest exploitation gravel road network (Figure 3).

Preferential ORV recreational activities on different parts of the Carpathian Mountains can be affected by various factors, such as type of car driving or motorbike riding and the time of year. The type of knowledge sought by our analyst included the pattern of tracks produced by the ORV, their flocking sites and frequent locations, especially in times of environmental stress. Gathering sites, in particular, revealed localized areas of endurance practice events leading to fuels leaching and exhaust emissions under specific conditions like compacted and wet soil. In the case of gathering areas for ORV practice, there is a distinction between motorbike sites and $4 \times 4$ vehicle sites [24]. A typical motorbike enduro forest routes system has a variety of drops and steep slope climbs, and natural obstacles like fallen trees and rocks that make the tracks chalenging. Carpathian Mountain access to gravel roads makes a perfect $4 \times 4$ enduro course network where all types of road legal $4 \times 4$ vehicles can usually enter with the maximum permitted size of their tyres of $97 \mathrm{~cm}$ tall and $33 \mathrm{~cm}$ wide. Tractor 
or dumper tyres used for deforestation activities are much bigger, representing the main destruction factor in the mountain environment.

\subsection{Discouraging Illegal Deforestation by ORV Presence}

We have been exploring Carpathian Mountain gravel roads on a regular basis for the past eight years, with confidence in the National Forest Administration's capacity for routes maintenance for deforestation purposes. The rush for timber represents the main problem all over the Transylvanian Mountains. Uncontrolled illegal deforestation started to affect even the protected areas, under the umbrella of so called maintenance legal cuts. Between 1995 and 2010, more deforestation was observed inside Natura 2000 protected areas than outside [3]. Approximately half, namely $48.95 \%$ of deforestation in the period of 2000 to 2011 took place in the current protected areas. Even worse, virgin forests were affected in the first place and they are among the most valuable.

According to Voda and Torpan, these woods can be found in Gurghiu Mountains-Batrana Peak area, where parts of valuable trees where illegally cut down [20]. Here we show the correlation in between onsite monitoring of old grown trees from Poieni ORV route and registered data on our virtual platform (Figure 4).

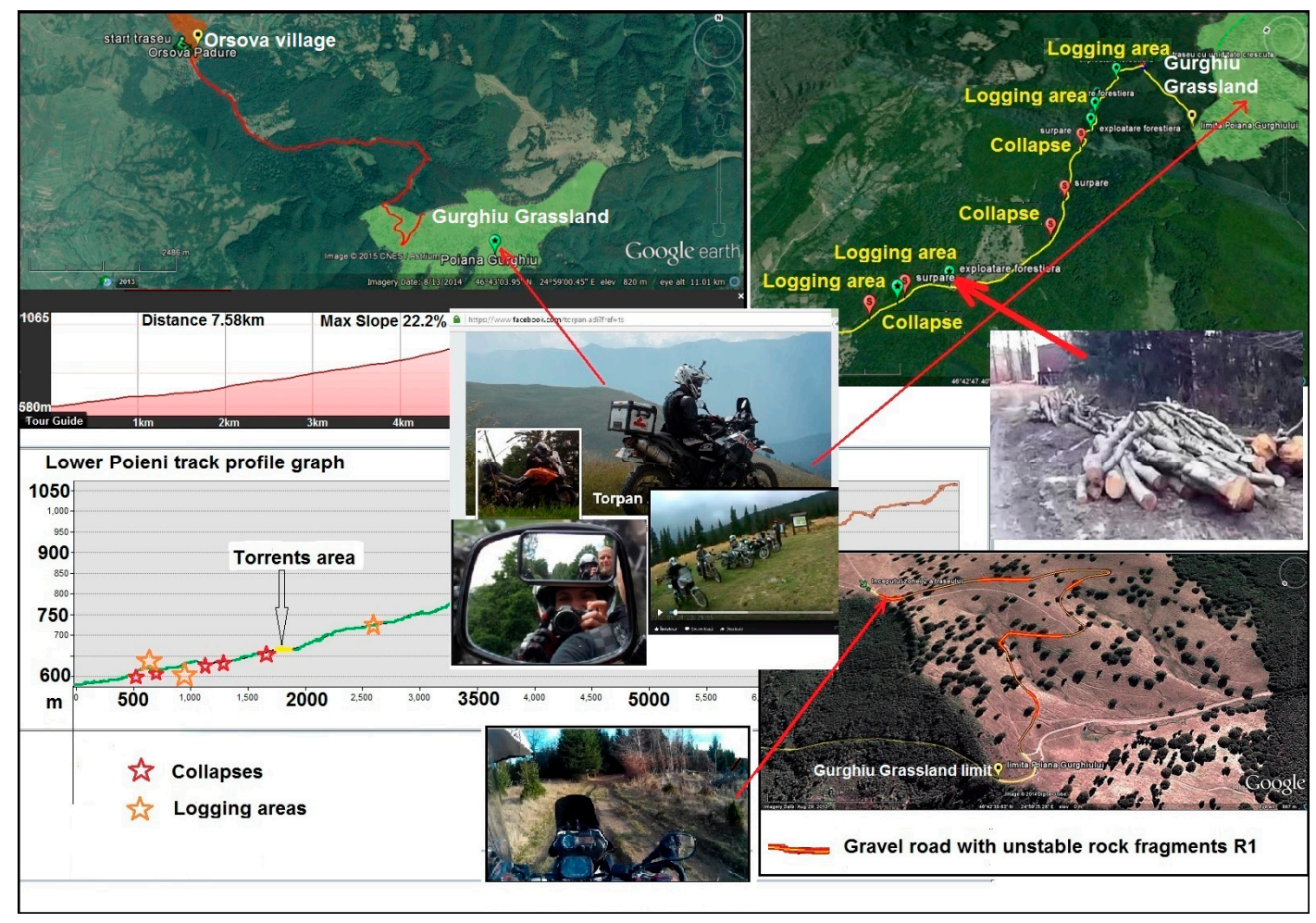

Figure 4. Poieni ORV route virtual platform model.

Our opinion is that Transylvanian protected areas administration development plan has to include the provisioning of recreational and cultural ecosystem services in order to better protect and preserve their natural areas. Mountain destinations are difficult to manage in order to balance the aims of both conservation and recreation, requiring practical experience to deal with the complexity of a mountain's social-ecological systems [25].

Our project aim was to encourage ORV recreational activities on recommended wilderness routes, legalized and supervised by the National Forest Administration [2]. Their constant presence in the woods will discourage illegal deforestation activities. 
The value of the wellbeing feeling coming from ORV recreation practitioners' relationship with Transylvanian nature is undeniable. They value these wild forests because they represent places enabling them to continue the ancestor's traditions. Eriksson et al. [26], found that there is no contradiction between forest recreational activities and biodiversity. The ecosystem goods and services satisfaction is not easily quantifiable because the unavailability of financial data but Costanza et al. (1997) determined that considerable ecosystem services already exists as public goods [27].

However, public access in the forest area is forbidden by the Romanian laws. Only organized leisure activities for tourism or sports purposes are allowed, with the regional forest administration office's pre-approval required on specific routes. An accurate classification of each route's risk based on GIS methodologies and geomorphological evaluation was needed to provide a secured recreational framework and low environmental impact of ORV's recreational activities. All this can be possible through the use of strict control of ORV recreational practice in an organized and well managed environment with clear rules established to ensure both the practitioners and vehicles security. This study creates a useful framing of the routes in terms of the slopes classification using GIS and global positioning system (GPS) for geomorphological and morphometric risks assessment of the exposed practitioners.

The Wild Carpathia ecosystem services or ecosystem goods have benefits that can hardly track each ORV movement after the check-in process. Compulsory connected to the vehicle battery, the entrance given phones with the preinstalled app will register every off-the-track action. Riders will enter for free and pay penalties upon exit if they go off of the designated ORV routes. Hein et al. (2006) evaluated the quality of services for recreational purpose that exist in a certain area in correlation to the extra transportation costs needed to reach the area from other places [28].

\section{Discussion}

It is generally agreed that deforestation activities damage the Wild Carpathia natural environment and most people consider that driving ORV on NFAA gravel roads may attract penalties but will reduce illegal logging.

As Colvin has observed, our results demonstrate that the growing ORV recreation popularity can be used in a sustainable way if it is well organized and controlled, with a permanent connection between the physical and virtual geographical space [29]. The ORV recreation frame model regulates social behaviour and coordinates mediated interactions between the public and nature. Wheaton [30] states that social media can provide a place on the internet to build community and norms around a geographical location or issue.

These findings suggest that National Forest Administration Authorities can effectively manage sustainable ORV recreation across the entire Carpathian range by providing desired recreation activities on a spatially optimized and well controlled forest exploitation track network near the gravel roads with limited access to random tracks into undisturbed areas [19].

The significance of our results has to be connected to the Transylvanian Mountains forest protection. Despite all anti-logging movements, illegal deforestation continues and more than that, remaining sites are deliberately maintained bare, without any replant initiatives. In the western countries it is impossible to ride a motorbike outside of a few specially designated areas. Even bicycles, horses and sometimes people have restricted access options in the natural geographical areas of the European Union. In the early 1990s, the environmental protection trend conquered every peak and the private land owners fenced all that remained. There were no tangible or intangible benefits in Western European countries, no ecosystem services to sustain and fulfil human life provided by the natural environment [31]. Beside ecosystem services, our ORV recreation frame model is meant to encourage controlled access and transparency of information about the state of every forest related area in collaboration with National Forest Administration Authorities. 
Today, many rich Romanian landowners are becoming richer with European funds coming as land subsidies payments. They do not have to produce food to receive these funds. Their land has to look agricultural, which means bare [32]. The land with ponds, wide hedges, regenerating woodland or trees sufficient to form a canopy, is considered ineligible so Romanian landowners realised that they can make money simply by cleansing the land. In the eastern parts of Transylvania, deforestation is done to sell cut trees and to ensure that the resulting surface qualifies for farm subsidies from the European Union. Our research results can be applied first in Gurghiu and the Caliman Mountains then extended everywhere, to start the process of reforestation and stop the illegal logging activities in all of the Transylvania mountains.

\section{Conclusions}

The mapping and analysis of ORV movement patterns in response to environmental conditions provided information for track design and optimisation and was used to identify ORV recreational activities preferences. Tracking ORV movements and gathering points provided quantitative information that may be useful to guide the process of Carpathian Mountains environmental protection.

Our recreation frame model will attract foreign visitors in search of the mythical Transylvania mountains, usually associated with Bram Stoker's Dracula, old vampires, impenetrable virgin forest full of wildlife, remote Hungarian castles, fortified Saxon churches and traditional Romanian villages. In recent years, ORV recreation opportunities have made Transylvania a new tourist destination for adventurers.

Given the technical characteristics of ORV, this analysis through GIS and GPS on the Carpathian Mountains forest tracks can provide an important tool in analyzing track specificity for all of the Transylvanian Mountain areas, allowing the creation of ORV recreational frameworks. GIS techniques gave us an important tool in evaluating accessibility and risk problems faced by ORV practitioners and also an instrument for exact orientation in the field and an excellent tool for the creation of other mountains future virtual platforms. Our findings suggest that National Forest Administration Authorities can effectively manage sustainable ORV recreation across the entire Carpathians range by providing desired recreation activities on a spatially optimized and well controlled forest exploitation track network.

Currently, European Union environmental policy regarding land use and natural ecosystems protection is substantially implemented in Romania through Natura 2000 protected areas [3]. A peculiar situation arises when we look at Wild Carpathia villages attacked by protected wild bears and villagers convicted for cutting firewood, while hunting ban stands and timber companies thrive on protected areas maintenance cuttings.

Our proposed ORV frame model will not replace hunting with poaching or illegal logging with mountain grassland clearing. It will raise public awareness of Wild Carpathia problems, enabling participatory planning with GIS, Remote Sensing and smartphone social network applications.

Romanian governmental authorities should focus more on the local communities' needs for better mountainous region management. Future development strategies for Wild Carpathia have to include ecosystem services and use modern technology to promote transparency in all governmental actions.

Acknowledgments: Dimitrie Cantemir University from Targu Mures, Romania, provided funds for covering the costs to publish in open access.

Author Contributions: V.M. and T.A. conceived and performed the field work, analyzed the data; M.L. contributed with the analysis tools; V.M. designed the virtual platform and wrote the paper.

Conflicts of Interest: The authors declare no conflict of interest. The founding sponsors had no role in the design of the study; in the collection, analyses, or interpretation of data; in the writing of the manuscript, and in the decision to publish the results.

\section{References}

1. Wild Carpathia. Available online: http://www.wildcarpathia.tv/ (accessed on 12 November 2015). 
2. Forest Law 133, Motorized Public Access into the National Forest Fund. Available online: http:// www.dreptonline.ro/legislatie/legea_133_2015_modificare_lege_46_2008_codul_silvic.php (accessed on 11 July 2015).

3. Gornic, O.G.; Voda, M. Transylvanian rural woods assessment using aerial and satelite imagery. Acad. Sci. J. Econ. Ser. 2014, 2, 62-70.

4. Sil, A.; Rodrigues, A.P.; Carvalho-Santos, C.; Nunes, J.P.; Honrado, J.; Alonso, J.; Marta-Pedroso, C.; Azevedo, J.C. Trade-offs and synergies between provisioning and regulating Ecosystem Services in a mountain area in Portugal affected by landscape change. Mt. Res. Dev. 2016, 36, 452-464. [CrossRef]

5. Veen, P.; Fanta, J.; Raev, I.; Biris, I.A.; De Smidt, J.; Maes, B. Virgin forests in Romania and Bulgaria: Results of two national inventory projects and their implications for protection. Biodivers. Conserv. 2010, 19, 1805-1819. [CrossRef]

6. Knorn, J.; Kuemmerle, T.; Radeloff, V.C.; Keeton, W.S.; Gancz, V.; Biris, I.A.; Svoboda, M.; Griffiths, P.; Hagatis, A.; Hostert, P. Continued loss of temperate old-growth forests in the Romanian Carpathians despite an increasing protected area network. Environ. Conserv. 2012, 40, 182-193. [CrossRef]

7. Knorn, J.; Kuemmerle, T.; Radeloff, V.C.; Szabo, A.; Mindrescu, M.; Keeton, W.S.; Abrudan, I.; Griffiths, P.; Gancz, V.; Hostert, P. Forest restitution and protected area effectiveness in post-socialist Romania. Biol. Conserv. 2012, 146, 204-212. [CrossRef]

8. Vanonckelen, S.; Van Rompaey, A. Spatiotemporal analysis of the controlling factors of forest cover change in the Romanian Carpathian Mountains. Mt. Res. Dev. 2015, 35, 338-350. [CrossRef]

9. Brown, G.G.; Reed, P. Public participation GIS: A new method for use in national forest planning. For. Sci. 2009, 55, 166-182.

10. Mihai, B.; Savulescu, I.; Sandric, I. Change detection analysis (1986-2002) of vegetation cover in Romania: A study of alpine, subalpine and forest landscapes in the Iezer Mountains, Southern Carpathians. Mt. Res. Dev. 2007, 27, 250-258. [CrossRef]

11. Brown, G.G.; Reed, P.; Harris, C.C. Testing a place-based theory for environmental evaluation: An Alaska case study. Appl. Geogr. 2002, 22, 49-76. [CrossRef]

12. Brown, G.G.; Smith, C.; Alessa, L.; Kliskey, A. A comparison of perceptions of biological value with scientific assessment of biological importance. Appl. Geogr. 2004, 24, 161-180. [CrossRef]

13. Kumar, M.; Kumar, P. Valuation of the ecosystem services: A psychocultural perspective. Ecol. Econo. 2008, 64, 808-819. [CrossRef]

14. Clement, J.M.; Cheng, A.S. Public Values and Preferences Regarding Forest Uses and Management on the Pike and San Isabel National Forests, Colorado; Survey Results; Department of Forest, Rangeland and Watershed Stewardship, Colorado State University: Fort Collins, CA, USA, 2006.

15. Boyd, J.; Banzhaf, S. What are ecosystem services? The need for standardized environmental accounting units. Ecol. Econo. 2007, 63, 616-626. [CrossRef]

16. MEA. Millennium Ecosystem Assessment. In Ecosystems and Human Well-being: Synthesis; Island Press: Washington, DC, USA, 2005.

17. Sherrouse, B.C.; Clement, J.M.; Semmens, D.J. A GIS application for assessing, mapping, and quantifying the social values of ecosystem services. Appl.Geogr. 2011, 31, 748-760. [CrossRef]

18. Wimpey, J.; Marion, J.L. A spatial exploration of informal trail networks within Great Falls Park, VA. J. Environ. Manag. 2011, 92, 1012-1022. [CrossRef] [PubMed]

19. Wescott, F.; Andrew, M.E. Spatial and environmental patterns of off-road vehicle recreation in a semi-arid woodland. Appl. Geogr. 2015, 62, 79-106.

20. Voda, M.; Torpan, A. Facebook and Youtube Role in Transylvanian Motorbike Tours Visualization Based on Remote Sensing Data. Acad. Sci. J. Geogr. Ser. 2014, 5, 60-64.

21. Voda, M.; Negru, R. Geomedia role in Mures Valley Castles tourism development between Ogra and Brancovenesti. Acad. Sci. J. Geogr. Ser. 2015, 6, 63-70.

22. Picnic Law 54/2012, Motorized Public Access into the National Forest Fund. Available online: https: / / www.legalis.ro/2012/03/29/legea-picnicului-legea-542012-amenzi-de-la-100-la-50000-de-lei/ (accessed on 14 June 2015).

23. Red Bull Romaniacs, the World's Toughest Hard Enduro Rallye. Available online: http://www. redbullromaniacs.com/start/red-bull-romaniacs-hard-enduro-rallye/ (accessed on 5 November 2015). 
24. Voda, M.; Moldovan, L.; Torpan, A.; Henning, A. Using GIS for mountain wild routes assessment in order to qualify them for tourism valorisation. Geogr. Technol. 2014, 9, 101-108.

25. Lai, P.S.; Hsu, Y.C.; Wearing, S. A social representation approach to facilitating adaptive co-management in mountain destinations managed for conservation and recreation. J. Sustain. Tour. 2016, 24, 227-244. [CrossRef]

26. Eriksson, L.; Nordlund, A.M.; Olsson, O.; Westin, K. Recreation in Different Forest Settings: A Scene Preference Study. Forests 2012, 3, 923-943. [CrossRef]

27. Costanza, R.; D'Arge, R.; De Groot, R.; Farber, S.; Grasso, M.; Hannon, B. The value of the world's ecosystem services and natural capital. Nature 1997, 387, 253-260. [CrossRef]

28. Hein, L.; Van Koppen, K.; De Groot, R.S.; Van Ierland, E.C. Spatial scales, stakeholders and the valuation of ecosystem services. Ecol. Econ. 2006, 57, 209-228. [CrossRef]

29. Colvin, R.M.; Witt, G.B.; Lacey, J. The social identity approach to understanding socio-political conflict in environmental and natural resources management. Glob. Environ. Chang. 2015, 34, 237-246. [CrossRef]

30. Wheaton, M.; Ardoin, N.M.; Hunt, C.; Schuh, J.S.; Kresse, M.; Menke, C.; Durham, W. Using web and mobile technology to motivate pro-environmental action after a nature-based tourism experience. J. Sustain. Tour. 2016, 24, 594-615. [CrossRef]

31. Daily, G.C. Introduction: What are ecosystem services? In Nature's Services: Societal Dependence on Natural Ecosystems; Daily, G.C., Ed.; Island Press: Washington, DC, USA, 1997; pp. 1-10.

32. Monbiot, G. Leave Well Alone. Available online: http://www.monbiot.com/2016/06/21/leave-well-alone/ (accessed on 22 June 2016).

(C) 2017 by the authors. Licensee MDPI, Basel, Switzerland. This article is an open access article distributed under the terms and conditions of the Creative Commons Attribution (CC BY) license (http:/ / creativecommons.org/licenses/by/4.0/). 